\title{
Inhibitory Effects of Pulse Bioactive Compounds on Cancer Development Pathways
}

\author{
Shiwangni Rao ${ }^{1,2} \mathbb{E}^{(1)}$, Kenneth A. Chinkwo ${ }^{1,2}$ (D), Abishek B. Santhakumar ${ }^{1,2, *(\mathbb{C})}$ \\ and Christopher L. Blanchard ${ }^{1,2}$ \\ 1 School of Biomedical Sciences, Charles Sturt University, Wagga Wagga, NSW 2650, Australia; \\ srao@csu.edu.au (S.R.); kchinkwo@csu.edu.au (K.A.C.); CBlanchard@csu.edu.au (C.L.B.) \\ 2 Australian Research Council (ARC) Industrial Transformation Training Centre (ITTC) for Functional Grains, \\ Graham Centre for Agricultural Innovation, Charles Sturt University, Wagga Wagga, NSW 2650, Australia \\ * Correspondence: asanthakumar@csu.edu.au; Tel.: +61-2-6933-2678
}

Received: 9 July 2018; Accepted: 30 July 2018; Published: 3 August 2018

\begin{abstract}
Previous studies suggest that pulses may have the potential to protect against cancer development by inhibiting pathways that result in the development of cancer. These pathways include those that result in inflammation, DNA damage, cell proliferation, and metastasis. Other studies have demonstrated extracts from pulses have the capacity to induce apoptosis specifically in cancer cells. Compounds reported to be responsible for these activities have included phenolic compounds, proteins and short chain fatty acids. The majority of the studies have been undertaken using in vitro cell culture models, however, there are a small number of in vivo studies that support the hypothesis that pulse consumption may inhibit cancer development. This review highlights the potential benefit of a diet rich in pulse bioactive compounds by exploring the anti-cancer properties of its polyphenols, proteins and short chain fatty acids.
\end{abstract}

Keywords: pulses; anti-cancer; antioxidant; polyphenols; peptides

\section{Introduction}

Pulses are edible seeds that belong to the legume family Fabaceae/Leguminosae, and are used for human consumption or as animal feed. The Food and Agriculture Organisation (FAO) listed 11 important types of pulses consumed around the world, including dry beans, dry broad beans, dry peas, chickpeas, dry cowpea, pigeon pea, lentil, groundnut, vetches, and lupin [1]. They are consumed for their high protein levels and carbohydrate rich endosperm. Pulses have also been demonstrated to contain bioactive compounds that alleviate risk factors associated with diabetes [2], metabolic syndrome [3], inflammation [4], and cancer [5,6].

There has been considerable interest in exploring the chemo-preventive properties of pulses and/or their derivatives using both in vitro and in vivo cancer models [7]. Some of the potential health beneficial properties of pulses have been attributed to the antioxidant activity exhibited by phenolic compounds [8,9], and/or the mechanistic involvement of proteins [10] and short chain fatty acids [11] in the disease process. This paper aims to review current literature describing the potential of pulses as effective anti-cancer nutraceutical agents. Specifically, the role that pulse derived phenolic compounds, proteins and fatty acids play in mechanistic pathways of anti-inflammatory, anti-apoptotic, anti-proliferative and anti-metastatic will be discussed.

\section{Bioactive Compounds in Pulses}

Pulses have a seed anatomy consisting of the endosperm, seed coat, and embryo (ridicule and root). The endosperm, which is the primary biomass of the seed, contains carbohydrates, storage proteins 
and fat. The seed coat of pulses are often rich in phenolic compounds [12], and studies have identified the presence of flavonoids, anthocyanins and tannins [12,13] (Figure 1). These phenolic compounds have high antioxidant activity [13] and their ability to scavenge free radicals has been correlated to anti-inflammatory [14,15], anti-proliferative [9] and anti-apoptotic activity. While crude extracts from pulses have been demonstrated to exhibit antioxidant activity, some pulse derived phenolic compounds such as anthocyanins [16] and iso-flavanols [17] have been demonstrated to be effective in targeting specific cancer pathways.

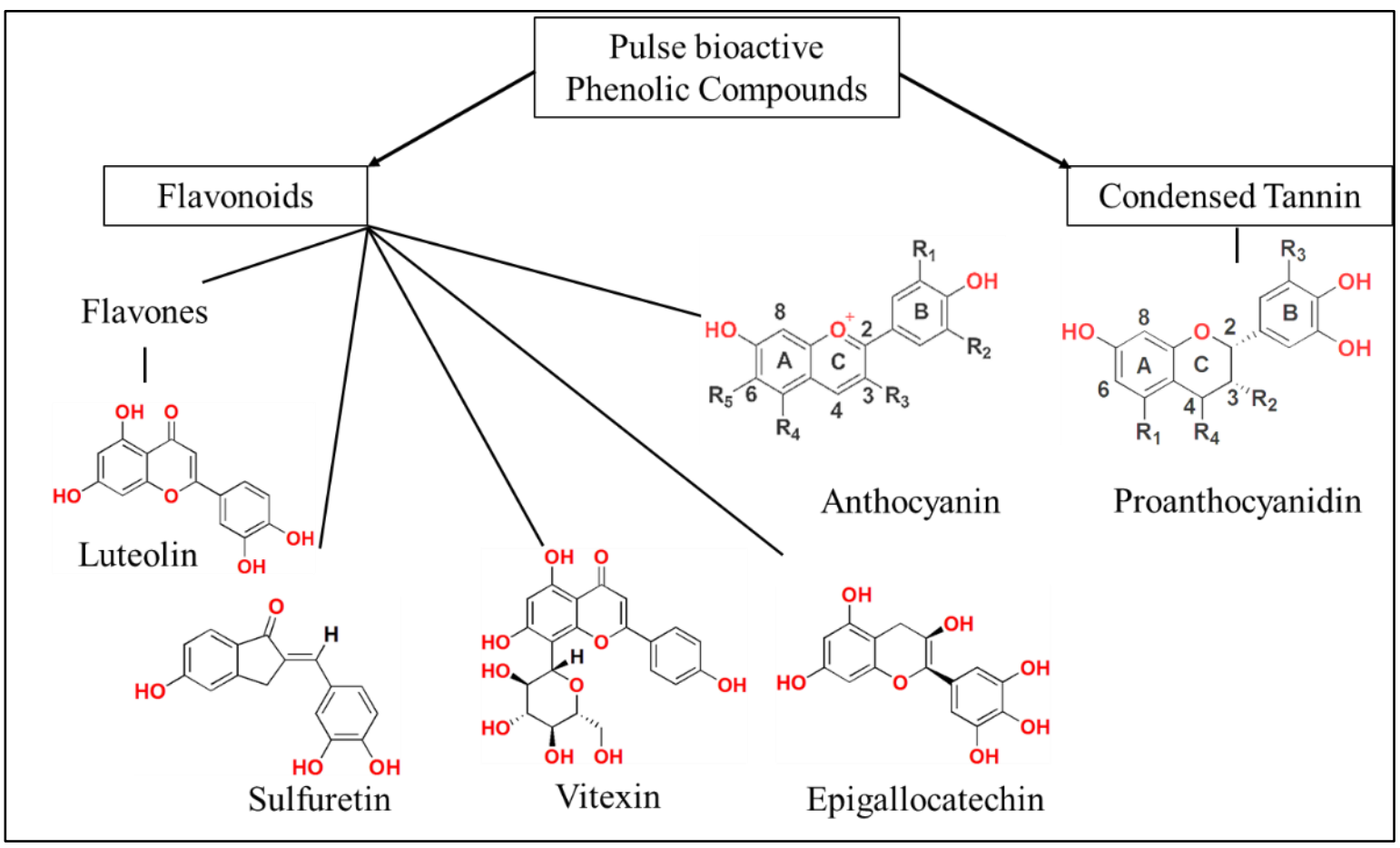

Figure 1. Bioactive flavonoids, anthocyanins, and tannins found in pulses.

Pulses contain proteins which are often classified as albumins, globulins, glutelins, and prolamins [18]. Some specific types of proteins such as lectins (carbohydrate-binding proteins) have been shown to exhibit anti-cancer properties [19]. For example. lectins derived from pulses are thought to bind to tumour membranes, blunt cellular proliferation, stimulate the immune system and induce apoptosis. Furthermore, protein protease inhibitors such as Bowman-Birk inhibitors (BBI), have been reported to target specific anti-cancer pathways [20]. Protease inhibitors have been found to have potential anti-cancer properties in in vitro and in vivo experiments by inhibiting the generation of reactive oxygen species. Pulses generally have low levels of lipids, however, fatty acids such as butyrate, oleic and linoleic acid have been associated with anti-cancer activities [11,21,22].

\section{Cancer Development and Mechanisms of Inhibition}

Transformation of normal cells into malignant cells due to mutations, result in genome instability of DNA molecules [23]. The mutated cancer cells develop salient characteristics to evade the immune system, sustain proliferative signalling, activates invasion with metastasis, resist cell death and initiate tumour promoting inflammation [23]. It has been reported that DNA damage from free radicals, increase cell cycle replication error from faulty tumour suppressors and inactivated repair machinery [24]. This scenario provides the right conditions to alter the mechanisms that regulate proliferation and apoptosis in normal cells with subsequent transformation into cancer cells.

By targeting specific points in cancer development pathways, pulse bioactive compounds have the potential to reduce the initiation and progression of cancer development and possibly play a 
role in the elimination of malignant cells. Incorporating pulses in diets have been shown to have beneficial effects against chronic conditions [25]. Correlations have been identified between pulse consumption and a reduction in inflammation and cancer development [26]. Studies have identified the anticancer potential of pulses including adzuki bean, black bean, mung bean, pinto bean, faba beans, lupins, lentils and chickpeas (Tables 1 and 2). It has been proposed that these pulses contain phenolic compounds, proteins and short chain fatty acids with the capacity to deter the progression of cancer cells development. These pulse bioactive compounds are thought to inhibit specific pathways to reduce cancer development by reducing inflammation, cancer cell proliferation and induce apoptosis specifically in cancer cells.

\subsection{Anti-Inflammation}

\subsubsection{Role of Pulse Phenolic Compounds}

Inflammation is the body's natural response mechanisms against foreign antigens. However, cancer-related inflammation has a cascading effect that leads to tumourigenesis [27]. Oxidative stress due to the presence of free radicals activates the enzyme IkB Kinase (IKK) which initiates the cellular nuclear factor kappa $\beta(\mathrm{NF}-\mathrm{k} \beta)$ pathway [28]. This results in other signal transduction pathways being activated such as the mitogen-activated protein kinase (MAPK) pathway which has been reported to promote cancer-related inflammation [27]. The activation of these pathways results in the production of cytokine signaling molecules/mediators such as cyclooxygenase (COX), tumour necrosis factor alpha (TNF- $\alpha$ ), and nitric oxide (NO). This, in turn, initiates the production of interleukin (IL), prostaglandin $\mathrm{E}_{2}\left(\mathrm{PGE}_{2}\right)$ and site-specific macrophage adhesion $[29,30]$. This disruption of the signaling network promotes the neighboring cells and tissue to support tumourigenesis [28].

Several studies have shown that phenolic compounds extracted from pulses have anti-inflammatory properties and free radical scavenging activity [31,32]. An in vitro experiment was conducted to investigate the anti-inflammatory effect of four bean varieties using colorectal cancer cell lines [32]. It was observed that all the bean extracts exerted an anti-inflammatory effect. It was confirmed that the level of the anti-inflammatory response was correlated to the anti-proliferative effect. Bean extracts were observed to inhibit pro-inflammatory proteins such as cyclooxygenase-2 (COX-2), tumour necrosis factor $\alpha$ (TNF $\alpha$ ), and nuclear factor kappa $\beta$ (NF- $k \beta$ ) while increasing the activity of interleukin 10 (IL-10), an anti-inflammatory protein. In another experiment, Faba beans inhibited inflammation via pro-inflammatory signal transduction pathway, mediated by Lipoxygenase (LOX) [14]. Furthermore, investigations were conducted on anti-inflammatory properties of phenolic extracts from mung bean cotyledon, hull, and whole grain [31]. It was observed that the hull with higher phenolic content and antioxidant activity had the highest anti-inflammatory effect. Lipopolysaccharide (LPS) stimulated RAW 264.7 mouse macrophage cells have also been reported to possess high anti-inflammatory properties in phenolic extracts from wholegrain mung bean [8].

\subsubsection{Role of Pulse Bioactive Peptides and Amino Acids}

Pulse proteins, peptides and amino acids have been demonstrated to exhibit anti-inflammatory effects. Protein hydrolysates from germinated beans have exhibited an anti-inflammatory effect in RAW 264.7 mouse macrophage cells by reducing nitric oxide synthesis [33]. Also, a non-protein amino acid, gamma-aminobutyric acid (GABA) has been shown to demonstrate anti-inflammatory activity. In vivo experiments using GABA-rich extracts were conducted on female Balb/c mice inoculated with Yac-1 and 4T1 carcinogenic cell lines [34]. Mice supplemented with diets of either $200 \mathrm{mg} / \mathrm{kg}$ or $1000 \mathrm{mg} / \mathrm{kg}$ body weight of GABA exhibited delayed tumour formation. This was correlated with high anti-cancer cytokine levels, splenic T cell populations, splenocyte cytotoxicity and spleen/tumour antioxidant levels. Mitotic divisions in spleen were also reduced which was accompanied by a reduction in antioxidant and nitric oxide levels [34]. 
Table 1. Anti-inflammatory potential of pulse bioactive compounds.

\begin{tabular}{|c|c|c|c|c|}
\hline Sample & Compound & Cell Line/Model & $\begin{array}{l}\text { Mechanisms/Outcomes of } \\
\text { Anti-Inflammatory Effect }\end{array}$ & Reference \\
\hline $\begin{array}{l}\text { Black, spotted and } \\
\text { common bean } \\
\text { (Phaseolus spp) }\end{array}$ & Phenolics & $\begin{array}{l}\text { HT-29 human } \\
\text { colon cancer cells }\end{array}$ & $\begin{array}{l}\text { Inhibition of pro-inflammatory } \\
\text { proteins cyclooxygenase-2 } \\
(\mathrm{COX}-2), \mathrm{TNF} \alpha \text { and NF- } \mathrm{\beta} \beta \\
\text { and increased expression of } \\
\text { anti-inflammatory protein IL-10. }\end{array}$ & [32] \\
\hline $\begin{array}{l}\text { Lentil (Lens } \\
\text { esculenta) Faba } \\
\text { bean (Vicia faba) }\end{array}$ & Phenolics & & $\begin{array}{l}\text { Faba bean hull extracts exhibited } \\
\text { mild LOX inhibitory activity, } \\
\text { while lentils inhibited 15-LOX, } \\
\text { COX-1 and COX-2. }\end{array}$ & [14] \\
\hline $\begin{array}{l}\text { Pigmented and } \\
\text { non-pigmented } \\
\text { beans (dry) } \\
\text { (Phaseolus spp) }\end{array}$ & Phenolics & $\begin{array}{l}\text { Female Sprague } \\
\text { Dawley rats }\end{array}$ & $\begin{array}{l}\text { Exhibited lowed incidences of } \\
\text { mammary cancer, cancer } \\
\text { multiplicity and tumour burden. }\end{array}$ & [35] \\
\hline $\begin{array}{l}\text { White kidney bean } \\
\text { (Ph. vulgaris) } \\
\text { Round purple bean } \\
\text { (Phaseolus spp) }\end{array}$ & Phenolics & $\begin{array}{l}\text { RAW } 264.7 \\
\text { macrophage cells }\end{array}$ & $\begin{array}{l}\text { Anti-inflammatory effect via a } \\
\text { reduction in LPS stimulated } \\
\text { macrophages of cytokine mRNA } \\
\text { expression and nitric oxide } \\
\text { production. }\end{array}$ & [36] \\
\hline $\begin{array}{l}\text { Adzuki bean }(\mathrm{Ph} . \\
\text { angularis) Mung } \\
\text { bean (Vigna radiate) }\end{array}$ & $\begin{array}{l}\text { Phenolics- hull and } \\
\text { cotyledon }\end{array}$ & & $\begin{array}{l}\text { Protease inhibition was highest in } \\
\text { hull faction followed by } \\
\text { wholegrain and cotyledon. }\end{array}$ & [31] \\
\hline $\begin{array}{l}\text { Mung bean } \\
\text { (Vigna radiate) }\end{array}$ & $\begin{array}{l}\text { Phenolics- vitexin and } \\
\text { isovitexin }\end{array}$ & $\begin{array}{l}\text { RAW } 264.7 \\
\text { macrophage cells }\end{array}$ & $\begin{array}{l}\text { Exhibited } \\
\text { anti-inflammatory effects. }\end{array}$ & [8] \\
\hline $\begin{array}{l}\text { Black Bean } \\
\text { (Phaseolus spp) }\end{array}$ & Protein hydrolysates & $\begin{array}{l}\text { RAW } 264.7 \\
\text { macrophage cell }\end{array}$ & $\begin{array}{l}\text { Nitric oxide synthesis was } \\
\text { inhibited when treated with } \\
\text { protein hydrolysates from } \\
\text { germinated beans }\end{array}$ & [33] \\
\hline $\begin{array}{l}\text { Chickpea } \\
\text { (Cicer arietinum) }\end{array}$ & & ICR male mice & $\begin{array}{l}\text { Reduction in the oxidation of } \\
\text { lipid, protein and DNA, } \\
\text { downregulation of } \\
\text { cyclooxygenase COX-2 and } \\
\text { inducible nitric oxide synthase } \\
\text { and oncogenic protein } \beta \text {-catenin. }\end{array}$ & [37] \\
\hline $\begin{array}{l}\text { Mung bean } \\
\text { (Vigna radiate) }\end{array}$ & $\begin{array}{l}\text { Gamma-aminobutyric } \\
\text { acid (GABA) }\end{array}$ & $\begin{array}{l}\text { Yac-1 and } 4 \mathrm{~T} 1 \\
\text { lymphoma cells } \\
\text { Female Balb/c } \\
\text { mice }\end{array}$ & $\begin{array}{l}\text { High anti-cancer cytokine levels, } \\
\text { spleen T cell populations, } \\
\text { splenocyte cytotoxicity, } \\
\text { and spleen/tumour antioxidant } \\
\text { levels. Mitotic divisions in spleen } \\
\text { were also reduced along with } \\
\text { antioxidant and nitric oxide levels. }\end{array}$ & [34] \\
\hline
\end{tabular}

Cyclooxygenase-2 (COX-2), tumour necrosis factor $\alpha$ (TNF $\alpha$ ), nuclear factor kappa $\beta$ (NF-k $\beta$ ), interleukin 10 (IL-10), Lipoxygenase (LOX).

\subsection{Anti-Proliferation}

\subsubsection{Role of Pulse Phenolic Compounds}

Several studies have investigated the anti-cancer potential of pules by demonstrating its anti-proliferative capacity in cancer cells $[6,14,16]$. Inhibition of cancer cell line proliferation was examined using phenolic extracts from pulses including green pea, yellow pea, chickpea, lentil, yellow soybean, black soybean, pinto bean, black bean, small red bean, red kidney bean, mung bean, adzuki bean and black-eyed peas on nine cancer cell lines [38]. The study found considerable variability in phenolic profiles and the effect these have on the various cell lines. Adzuki exhibited the highest anti-proliferative effect in a dose-dependent manner in cell lines CAL27, AGS, HepG2, SW480, Caco-2, DU 145, SK-OV-3, MCF-7 and HL-60. Inhibition of proliferation was observed at $\mathrm{IC}_{50} 0.32,0.68,0.36$, $0.4,0.41,1.98,0.79,0.86$ and $0.55 \mathrm{mg} / \mathrm{mL}$ respectively. Meanwhile, the black-eyed pea, green pea, 
yellow pea and chickpea extracts did not establish an $\mathrm{IC}_{50}$ value, with substantial anti-proliferative effect in the cell lines HepG2, Caco-2, DU145 and SK-OV-3 [38].

Another study examined the effect of phenolic extracts from raw, cooked and fermented Canavalia beans of two types, on HT29 and MCF7 cell lines [39]. It was found that the fermented Canavalia cathartica and cooked Canavalia maritima were more effective in inhibiting cell proliferation compared to their raw forms. The study deduced that processing by cooking and fermentation significantly increased anti-proliferative properties in canavalia beans. Meanwhile, phenolic compounds extracted from sprouted and dry mung beans have also demonstrated anti-proliferative effects [40]. The study extracted phenolic compounds with methanol, ethanol, hexane, water and butanol and tested their effect on Calu6 and SNU601 cell lines. It was observed that ethanol extracts and extracts from sprouts were more effective at inhibiting proliferation with extracts from sprouted beans having higher anti-proliferative effects.

The effects of pulse pigmentation in relation to inhibition of cancer cell lines proliferation has also been examined [41]. The study used phenolic extracts from 12 pigmented and non-pigmented varieties of bean which were tested using Caco-2, MCF7 and A594 cancer cell lines. It was observed that pigmented varieties were more toxic to cancer cells compared to non-pigmented varieties, with Cannellino Ross having the highest cytotoxicity. While the aforementioned studies have investigated effects of crude phenolic extracts, some studies have identified specific phenolic compounds with anti-proliferative effects $[5,42]$. These studies identified condensed tannins, isoliquiritigenin, 6, $4^{\prime}$-dihydroxy-3'-methoxyaurone, and sulfuretin as possible cytotoxic phenolic compounds present in red bean and tokan bean. In addition, an in vivo study demonstrated female Sprague Dawley rats to have reduced incidences of mammary cancer, multiplicity and tumour size, when fed with bean extracts [35]. Rat diets consisted of $60 \%$ bean extract from white kidney, dark red kidney, great northern, small red, navy and black bean. In contrast, to previously mentioned study [41], this study proposes that the origin of cultivation correlated more closely to the anti-proliferative effects rather than the phenolic content or pigmentation level [35].

\subsubsection{Role of Pulse Bioactive Proteins}

Protein isolates derived from pulses have also been investigated for their anti-proliferative effects. Mung bean protein extracts have been observed to have a stronger anti-proliferative effect than Adzuki bean extracts when using SKOVE and SMMC7721 cancer cells ( $\mathrm{IC}_{50}$ of 505.1 and $323.6 \mu \mathrm{g} / \mathrm{mL}$ respectively) [43]. Other studies using protein fractions of large red (Nepalese) [44] and spotted beans [45] found that proliferation was inhibited in L1210 and MBL2 by both bean extracts. Spotted bean had a higher anti-proliferative effect compared to red bean with an $\mathrm{IC}_{50}$ value of $4 \mu \mathrm{M}$ in L1210 and $9 \mu \mathrm{M}$ in MBL2 cell lines. Moreover, protease inhibitor peptides from chickpea, kidney bean, mung bean, peas and lentils have also been investigated for their anti-proliferative potential [46]. From the five pulses examined, chickpea protease inhibitors were observed to be the most effective at inhibiting MDA-MB-231 proliferation, compared to other pulses.

Mung bean protein extracts have been demonstrated to inhibit proliferation in cancerous cells (MCF7 and Hela cells) while slightly inhibiting proliferation of normal fibroblast cells [47]. In addition, other in vitro investigations using various cancer cell lines have demonstrated anti-proliferative effects of isolated protein extracts including; Hemagglutinin-French bean [48], Homotetrameric-Haricot bean [49], Limynin-Lima beans [50], Coccinin—Scarlet bean [51], Mugoin-Mung bean [52], Lectin-Pinto beans [53], trypsin inhibitor-White cloud bean [54], Bowman-Birk inhibitors (BBI)-Peas [55], water-soluble protein extracts [56], and C25 protein fractions [57] from chickpea.

\subsubsection{Role of Short-Chain Fatty Acids}

A limited number of studies have investigated the anti-proliferative effects of short chain fatty acids from pulses. The role of fatty acids in conjunction with coumarins from alhagi beans has been examined on C32 melanoma cells. The study found that short-chain fatty acids from alhagi 
beans inhibited proliferation with an $\mathrm{IC}_{50}$ value of $2700 \mathrm{mg} / \mathrm{mL}$ [58]. An in vivo analysis utilized Azoxymethane to induce colon cancer in rats [59]. The rats were fed with $75 \%$ Black bean and Navy bean short chain fatty acid, Butyrate. Rats fed with a diet of black bean or navy bean had reduced incidences of colon adenocarcinoma and total tumour multiplicity. The reduction in carcinogenesis from the diet was attributed to reduced body fat due to the presence of butyrate in the distal colon.

\subsection{Pro-Apoptotic Effects of Pulses}

\subsubsection{Pro-Apoptotic Bioactive Phenolic Compounds}

In addition, to inhibition of inflammation and cancer cell proliferation, phenolic compounds from pulses have also been recognised as inducers of apoptosis (Table 2). The effect of faba bean phenolic extracts was examined on several human cancer cell lines [6]. The phenolic extracts were found to inhibit proliferation of cancer cells and specifically induce apoptosis in leukaemia cells while inhibiting angiotensin-converting-enzyme (ACE), $\alpha$-glucosidase and pancreatic lipase. Studies have also investigated phenolic extracts of jamapa beans on HeLa and HaCaT cells $[24,60]$. Apoptotic induction in Hela cells was achieved by upregulation of pro-apoptotic proteins such as Bax and caspase3. Korean kidney bean phenolic extracts have also been identified to induce apoptosis through the Activated Protein Kinase (AMPK) signalling pathway [10]. This involved upregulation of proteins such as p-AMPK, p-Acc, p53 and p21 as a result of inhibition of AMPK by the interaction of compound $C$ with AMPK activator 5-Aminoimidazole-4-carboxamide ribonucleotide (AICAR) [10].

Phenolic extracts from mung bean sprouts have been demonstrated to reduce inflammation, induce anti-proliferative effect and apoptosis in HeLa and HepG2 cells [61]. It was observed that the mung bean extracts upregulated TNF $\alpha$ and IFN- $\beta$, while inducing expression of IFN $\gamma$, apoptotic genes, tumour suppressor genes and inhibiting IL-4. A similar investigation has been conducted on phenolic extracts of lentil and pea sprouts [62]. The study revealed that in green non-sprouted and yellow sprouted pea, a $50 \%$ cytotoxicity was observed at $3 \mathrm{mg} / \mathrm{mL}$ [62]. Furthermore, in the sprouted green pea, sprouted lentil and non-sprouted lentils, induced cytotoxicity was seen at $6 \mathrm{mg} / \mathrm{mL}$ and in yellow non-sprouted pea at $7.5 \mathrm{mg} / \mathrm{mL}$. The apoptotic effect of the extracts was linked to the induction of lactate dehydrogenase enzyme (LDH) release, DNA fragmentation and upregulation of caspase3 activity. An in vivo study incorporated red kidney bean phenolic extracts into female Sprague Dawley rats diet and found rats fed with the extract had lower mammary cancer incidences, multiplicity and tumour size [63]. The mechanism of action was identified as the mitochondrial pathway involving up-regulation of Bcl-2 associated X protein and down-regulation of B cell lymphoma 2 and X-linked inhibitor protein.

Furthermore, specific phenolic compounds responsible for activation of apoptosis have also been identified. For instance, flavonoid extracts from black bean hulls have been found to have pro-apoptotic effects on OCI-Ly7 lymphoma cells in mouse. It was believed that flavonoids have an effect on cell cycle by inducing cell cycle arrest at the S-phase and blocking progression to G2/M phase [64]. Isoflavones from chickpeas were observed to have cytotoxic effects at $\mathrm{IC}_{50}$ of $10-60 \mu \mathrm{g} / \mathrm{mL}$ as the extract upregulated cytoclasis, apoptotic body formation, caspase7, caspase9 and p53 [17]. It further showed a decrease in the following; P21, mitochondrial membrane potential, expression of Bcl-2-associated X protein but an increase in Bcl-2. Additionally, epigallocatechin and luteolin present in pea phenolic compound extracts have been linked to apoptotic activity induced in LS174, MDA-MB-453, A594 and K562 cancer cell lines [65]. The study found that these phenolic compounds were linked to darker pigmented pea varieties. Potential activation of apoptosis was identified via caspase3 pathway.

\subsubsection{Pro-Apoptotic Bioactive Peptides}

Peptides extracted from pulses have been shown to exhibit a considerable effect in inducing apoptosis (Table 2). Non-digestible fractions from fermented beans of four different types including 
Azufrado higuera, Bayo madero, Negro 8025, and Pinto Durango have been examined for pro-apoptotic potential [66]. Extracts from the beans induced apoptosis in HCT116, RKO, and KM12L4 cancer cell lines. The investigation also established that extracts from all the four types exerted an anti-proliferative effect. Azufrado higuera upregulated cell cycle arrest markers such as p53 Ser ${ }^{392}$, p21 and downregulated cyclin-B1. Meanwhile, Bao Madero induced apoptosis through the mitochondrial pathway affected the transmembrane receptor TNFR1 and induced modification of markers including BAD, cytC, c-casp3, survivin and BIRC7 [66].

Further investigation isolated the aforementioned peptides from Large lima beans to examine the mechanistic pathways involved in inducing apoptosis by ACE inhibitor proteins [67]. The non-digestible fraction consisted of $70 \%$ protein, rich in ACE inhibitors, was sequenced as GLTSK, LSGNK, GEGSGA, MTEEY, and MPACGSS. It was demonstrated that the ACE inhibitor proteins GLTSK and GEGSGA were the most effective in inhibiting cell proliferation. GLTSK induced mitochondrial membrane disruption, by the loss of mitochondrial membrane potential and a 12.1-fold increase in reactive oxygen species. While GEGSGA initiated DNA damage by promoting poly-ADP-ribose polymerize (PARP) cleavage and halting cell cycle in G1phase. Consequently, activating oxaliplatin initiated the translocation of p53 protein in the apoptotic signal pathway. Similar mitochondrial dysfunction was observed when HCT116 and HT29 colorectal cancer cell lines were treated with hemagglutinin fraction from the black bean [68].

Furthermore, anti-proliferative activity of WKBL lectin from white kidney beans have been examined on HONE1, HepG2, MCF7 and WRL68 cancer cells [69]. The study showed that the anti-proliferative activity in HONE1 cells and HepG2 cells were high, while activity in MCF7 and WRL68 cells was considerably lower. Apoptosis was induced through the extrinsic pathway. The pathway involved upregulation of caspase 3, 8 and 9 in cells affected by WKBL treatment. Lectin found in lentils has demonstrated apoptotic activity through the extrinsic apoptotic pathway, the mechanism of action was through caspase 3, 8, and 9 as detected in CNE1 cells [70]. Additional apoptotic pathways were identified by phosphatidylserine externalization, mitochondrial depolarization and cell cycle arrest [70].

The anti-proliferative effect of proteins has also been investigated via the inhibition of glucose-regulated protein 78 (GRP78)—present only in cancerous cell membrane [71]. In the study, WIFPWIQL was formed using a GRP78 binding peptide and mung bean trypsin inhibitor protein. The synthesised protein was tested in vitro and in vivo. Cancer cell lines of HT29, SW620 and DLD1 exhibited apoptotic deaths while the normal cell line of FHC was unaffected. Xenografts in mice induced with human colorectal carcinoma also demonstrated reduced tumourigenesis. A potential pathway of apoptosis was through binding and activation of the constructed protein to GRP78, consequently, activating multiple apoptotic pathways and inducing G1 phase arrest [71].

\subsubsection{Pro-Apoptotic Pulse Short-Chain Fatty Acids}

Anti-proliferative effects of short chain fatty acids have been associated with the induction of apoptosis [11,72,73]. Apoptotic induction by DNA fragmentation utilizing butyrate derived from black beans has been examined in HT29 cells [11] (Table 2). Further investigation indicated that the apoptotic effect was due to the modulation of RB1, CDC2, CDC25A, NFk $\beta$, and E2F genes [73]. In addition, an increase was observed in the pro-apoptotic genes APAF1, BID, CASP9, FASLG, TNFR10B, and Bcl2A. In vivo investigations of butyrate derived from black bean tested on male Sprague Dawley rats treated with $1.84 \mathrm{~g} / \mathrm{kg}$ lyophilized samples induced substantial levels of apoptosis [72]. Lowering the number of total colonic Aberrant Crypt Foci initiated cell cycle arrest the G1 phase. 
Table 2. Pro-apoptotic pathways initiated by pulse bioactive compounds.

\begin{tabular}{|c|c|c|c|c|}
\hline Sample & Compound & Cell Line/Model & Mechanisms for Apoptosis & Reference \\
\hline $\begin{array}{l}\text { Black Bean } \\
\text { (Phaseolus spp) }\end{array}$ & $\begin{array}{l}\text { Phenolics-hulls extract and } \\
\text { flavonoid fraction }\end{array}$ & OCI-Ly7 lymphoma cells mouse & $\begin{array}{l}\text { Induced cell population to S-phase, increased the } \\
\text { overall survival of mice fed with bean extracts by } \\
\text { blocking progression to } \mathrm{G} 2 / \mathrm{M} \text { phase. }\end{array}$ & [64] \\
\hline $\begin{array}{l}\text { Black Bean } \\
(\text { Phaseolus spp) }\end{array}$ & Phenolics & $\begin{array}{l}\text { HeLa human cervical cancer cells } \mathrm{HaCaT} \\
\text { human premalignant keratinocytes }\end{array}$ & $\begin{array}{l}\text { Reduced number of cells in the G0/G1 phase in } \\
\text { comparison to control and induced apoptosis. }\end{array}$ & [60] \\
\hline $\begin{array}{l}\text { Black Bean } \\
(\text { Phaseolus spp) }\end{array}$ & Phenolics & HeLa human cervical cancer cells & $\begin{array}{l}\text { Methanol extracts induced apoptosis via upregulation } \\
\text { of pro-apoptotic proteins, Bax and Caspase- } 3 \text {. }\end{array}$ & [24] \\
\hline $\begin{array}{l}\text { Mung bean sprouts } \\
\text { (Vigna radiate) }\end{array}$ & Phenolics & $\begin{array}{l}\text { HeLa human cervical cancer cells, HepG2 } \\
\text { human liver cancer cells }\end{array}$ & $\begin{array}{l}\text { Regulation of tumour necrosis factor (TNF- } \alpha \text { ), } \\
\text { Interferon (FN- } \beta \text {, IFN } \gamma \text { ), Interleukin (IL-4), apoptotic } \\
\text { genes and tumour suppressor genes. }\end{array}$ & [61] \\
\hline $\begin{array}{l}\text { Red beans (dry) } \\
\text { (Phaseolus spp) }\end{array}$ & Phenolics-isoflavones & Female Sprague Dawley rats & $\begin{array}{l}\text { Increase in pro-apoptotic proteins BCL-2-associated X } \\
\text { protein and reduction in inhibitory apoptotic protein B } \\
\text { cell lymphoma } 2 \text { and X-linked inhibitor, hence induction } \\
\text { of apoptosis was via the mitochondrial pathway. }\end{array}$ & [63] \\
\hline $\begin{array}{l}\text { Peas (Cajanus cajan) } \\
\text { Lentil (Lens esculenta) }\end{array}$ & Phenolics & Caco-2 human colon cancer cell & $\begin{array}{l}\text { Apoptotic action was linked to the induction of lactate } \\
\text { dehydrogenase (LDH) release, DNA fragmentation and } \\
\text { upregulation of caspase- } 3 \text { activity. }\end{array}$ & [62] \\
\hline Peas (Cajanus cajan) & $\begin{array}{l}\text { Phenolics_epigallocatechin } \\
\text { and luteolin }\end{array}$ & $\begin{array}{l}\text { LS174 human colon adenocarcinoma, } \\
\text { MDA-MB-453 human breast carcinoma, } \\
\text { A594 human lung carcinoma, K562 } \\
\text { myelogenous leukaemia }\end{array}$ & Induction of caspase 3 pathway. & [65] \\
\hline $\begin{array}{l}\text { Chickpea } \\
\text { (Cicer arietinum) }\end{array}$ & Phenolics-isoflavones & SKBr3, MCF-7 human breast cancer cells & $\begin{array}{l}\text { Upregulation of cytoclasis, apoptotic body formation, } \\
\text { caspase 7, caspase 9, P53, and P21 decrease in } \\
\text { mitochondrial membrane potential, expression of } \\
\text { Bcl-2-associated X protein and increased Bcl-2. }\end{array}$ & [17] \\
\hline $\begin{array}{l}\text { Korean kidney bean } \\
\text { husk (Ph. vulgaris) }\end{array}$ & Phenolics & HT-29 human colon cancer cells & $\begin{array}{l}\text { Upregulation of proteins adenosine } \\
\text { monophosphate-activated protein kinase (p-AMPK), } \\
\text { protein acetyl-CoA carboxylase (p-ACC), p53 and p21. }\end{array}$ & [10] \\
\hline $\begin{array}{l}\text { Speckled lentil (Lens } \\
\text { esculenta; Ervum lens) }\end{array}$ & Peptide-lectin & $\begin{array}{l}\text { Nasopharyngeal carcinoma CNE1 and } \\
\text { CNE2 cells }\end{array}$ & $\begin{array}{l}\text { Phosphatidylserine externalization, mitochondrial } \\
\text { depolarization and cell cycle arrest. An extrinsic } \\
\text { apoptotic pathway involving caspase } 3,8 \text {, and } 9 \text { were } \\
\text { also detected in CNE1 cells }\end{array}$ & [70] \\
\hline $\begin{array}{l}\text { Black Bean } \\
\text { (Phaseolus spp) }\end{array}$ & Peptide-hemagglutinin & HCT116, HT-29 human colon cancer cells & $\begin{array}{l}\text { Hemagglutinin successfully penetrate the cytoplasm of } \\
\text { colorectal cancer cells and instigate mitochondrial } \\
\text { dysfunction and apoptotic activity }\end{array}$ & [68] \\
\hline
\end{tabular}


Table 2. Cont

\begin{tabular}{|c|c|c|c|c|}
\hline Sample & Compound & Cell Line/Model & Mechanisms for Apoptosis & Reference \\
\hline $\begin{array}{l}\text { Mung bean } \\
\text { (Vigna radiate) }\end{array}$ & $\begin{array}{l}\text { Peptide-GRP78 binding } \\
\text { peptide WIFPWIQL and the } \\
\text { active fragment of mung bean } \\
\text { trypsin inhibitor }\end{array}$ & $\begin{array}{l}\text { HT-29, SW620, DLD1 human colon } \\
\text { cancer cell, FHC human normal colon } \\
\text { cells, female mice with severe combined } \\
\text { immune deficiency (SCID/NOD) }\end{array}$ & $\begin{array}{l}\text { Activation of multiple apoptotic pathways and } \\
\text { induction of G1 phase arrest. }\end{array}$ & [71] \\
\hline $\begin{array}{l}\text { White kidney bean } \\
\text { (Ph. vulgaris) }\end{array}$ & Peptide—WKBL (lectin) & $\begin{array}{l}\text { HONE1 epithelial tumour cells } \\
\text { HepG2 human liver cancer cells } \\
\text { MCF-7 human breast cancer cells } \\
\text { WRL68 human normal adherent cells }\end{array}$ & $\begin{array}{l}\text { Caspase } 3,8 \text { and } 9 \text { were upregulated in cells as a result } \\
\text { of WKBL treatment outlining apoptosis as the } \\
\text { mechanism of action following an extrinsic pathway. }\end{array}$ & [69] \\
\hline $\begin{array}{l}\text { Black, spotted and } \\
\text { common bean } \\
\text { (Phaseolus spp) }\end{array}$ & Peptides & $\begin{array}{l}\text { HCT116, RKO, KM12L4 human } \\
\text { colorectal cancer cells }\end{array}$ & $\begin{array}{l}\text { P53 expression was up-regulated along with } \\
\text { modification of p21 and cyclin B1 }\end{array}$ & [66] \\
\hline $\begin{array}{l}\text { Large Lima beans } \\
\text { (Ph. lunatus) }\end{array}$ & $\begin{array}{l}\text { Peptides-GLTSK, LSGNK, } \\
\text { GEGSGA, MTEEY, } \\
\text { and MPACGSS }\end{array}$ & $\begin{array}{l}\text { HCT116, CCD-33Co human normal } \\
\text { colon cells }\end{array}$ & $\begin{array}{l}\text { GLTSK caused mitochondrial membrane disruption via } \\
\text { loss of mitochondrial potential }(\Delta \psi \mathrm{m}) \text { and increased } \\
\text { intracellular ROS. GEGSGA caused DNA damage via } \\
\text { cleavage of PARP and cell cycle arrest in G1 phase, } \\
\text { suggesting oxaliplatin initiated activation and nuclear } \\
\text { translocation of p53. }\end{array}$ & [67] \\
\hline $\begin{array}{l}\text { Black Bean } \\
\text { (Phaseolus spp) }\end{array}$ & Short-chain fatty acid & HT-29 human colon cancer cells & $\begin{array}{l}\text { Modulation of: RB1, CDC2, CDC25A, NFKB and E2F } \\
\text { genes; and pro-apoptotic genes: APAF1, BID, CASP9, } \\
\text { FASLG, TNFR10B and BCL2A genes. }\end{array}$ & [73] \\
\hline $\begin{array}{l}\text { Black Bean } \\
\text { (Phaseolus spp) }\end{array}$ & $\begin{array}{l}\text { Short-chain fatty } \\
\text { acids-butyrate }\end{array}$ & Male Sprague Dawley rats & $\begin{array}{l}\text { Rats demonstrated apoptotic effects and cell cycle arrest } \\
\text { in G1 phase. }\end{array}$ & [72] \\
\hline $\begin{array}{l}\text { Black Bean } \\
\text { (Phaseolus spp) }\end{array}$ & $\begin{array}{l}\text { Short-chain fatty } \\
\text { acids-butyrate }\end{array}$ & HT-29 human colon cancer cells & $\begin{array}{l}\text { DNA fragmentation induced by the extracts indicating } \\
\text { that cells were undergoing apoptosis. }\end{array}$ & [11] \\
\hline Bean (Phaseolus spp) & $\begin{array}{l}\text { Polysaccharides_-human gut } \\
\text { fermented bean }\end{array}$ & HT-29 human colon cancer cells & $\begin{array}{l}\text { Extract induced apoptosis via modulation of } 72 \\
\text { p53-mediated signal transduction response genes in } \\
\text { human colorectal cancer cells }\end{array}$ & [74] \\
\hline
\end{tabular}




\subsection{Anti-Metastatic Effects of Pulses}

A limited number of studies have investigated the anti-metastatic potential of pulses. One such study examined the anti-metastatic potential of the chickpea, lentil, lupin, common bean, peas, faba bean, and cowpea, using HT29 cells [75]. It was observed that the albumin and globulin fractions from seeds inhibit cell proliferation at $100 \mu \mathrm{g} / \mathrm{mL}$, with lupin and peas extracts displaying the highest and lowest anti-metastatic activity respectively. The study showed that, cell proliferation, correlated to anti-metastatic ability and that MMPIs present in these seeds to be novel metalloproteinase inhibitors. In addition, investigations on the anti-metastatic properties of pulses has been examined by evaluating the effect of protease inhibitor from field beans on mice injected with melanoma cells [76]. Two treatment approaches were investigated, firstly, melanoma cells were treated with extract pre-induction to mice and secondly by feeding mice with diets of $100 \mathrm{mg} / \mathrm{kg}$ of extract post induction of melanoma cells. Both approaches effectively reduced migration of metastatic lung melanoma cells by plasmin inhibitory action. Although the two studies have identified pulse protein factions to have potential anti-metastatic effect in vitro and in vivo, further research is warranted to understand the exact mechanism of action associated with MMP/protease inhibition.

\section{Conclusions}

The studies discussed in this review suggest that pulses may play an important role in reducing the risk of cancer occurrence and deterring its progression via diverse mechanisms. These mechanisms include reducing inflammation and cancer cell proliferation/metastasis as well as the induction of apoptosis in cancer cells. Figure 2 provides a summary of how bioactive compounds from pulses may play a role in the reduction of cancer development and progression. Although the studies outlined in this review demonstrate the potential anti-cancer properties of pulses, as well as the impact that processes such as sprouting and cooking, may have on these activities, more research is needed to confirm these activities using in vivo human clinical trials.

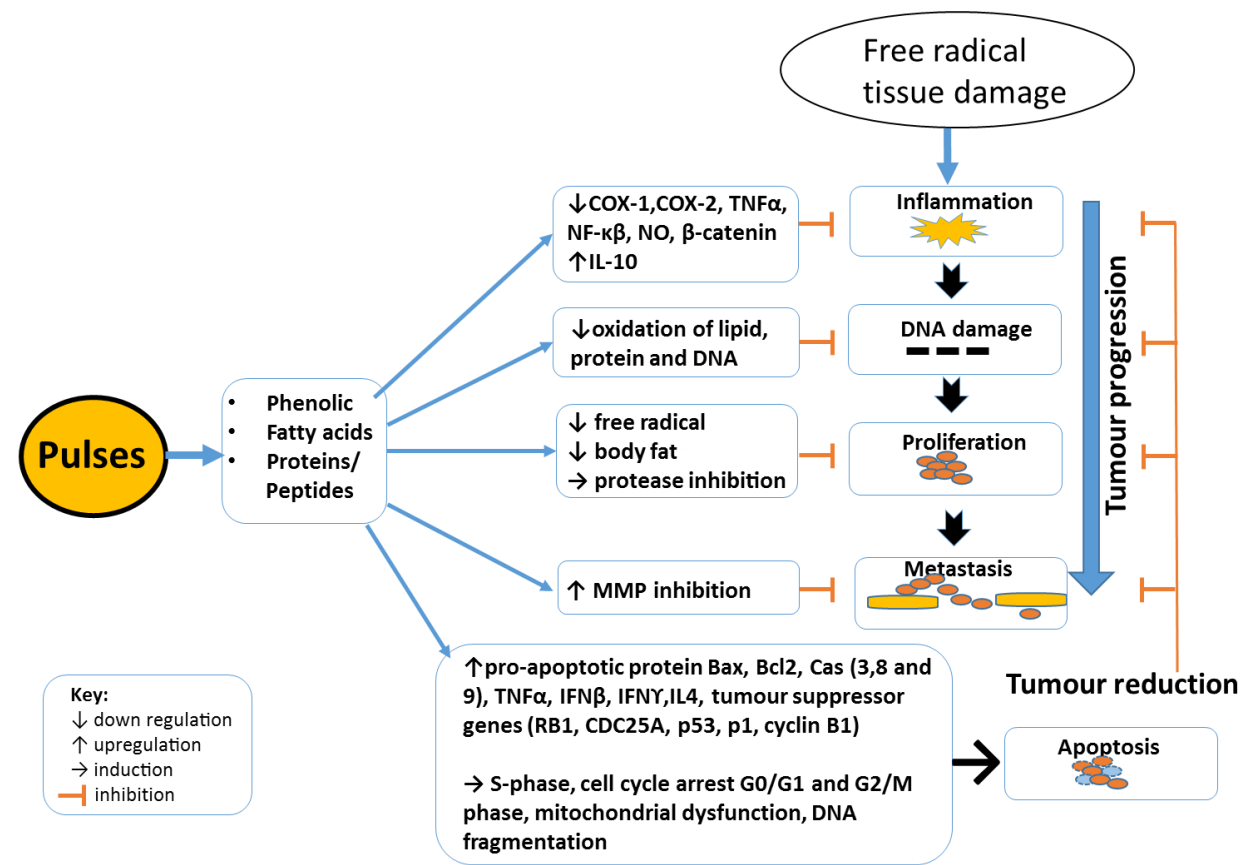

Figure 2. Potential interaction of pulse bioactive compounds with cancer pathways. Cyclooxygenase (COX), tumour necrosis factor $\alpha(\mathrm{TNF} \alpha)$, nuclear factor kappa $\beta$ (NF-k $\beta)$, interleukin (IL), interferon (IFN), (LOX), nitric oxide (NO), matrix metalloproteinase inhibitors (MMPI). 
Author Contributions: Conceptualization, K.A.C. and A.B.S.; Methodology, S.R., K.A.C. and A.B.S.; Validation, K.A.C., A.B.S. and C.L.B.; Formal Analysis, S.R.; Investigation, S.R; Resources, C.L.B.; Data Curation, S.R; Writing-Original Draft Preparation, S.R, K.A.C and A.B.S.; Writing-Review \& Editing, S.R, K.A.C., A.B.S. and C.L.B.; Visualization, S.R, K.A.C., A.B.S. and C.L.B.; Supervision, K.A.C., A.B.S. and C.L.B.; Project Administration, A.B.S.; Funding Acquisition, C.L.B.

Funding: This research was funded by Australian Research Council Industrial Transformations Centre for Functional Grains grant number IC140100027.

Conflicts of Interest: The authors declare no conflict of interest.

\section{References}

1. Food and Agriculture Organisation. Pulses and Derived Products. Available online: http://www.fao.org/ es / faodef/fdef04e.htm (accessed on 30 June 2018).

2. Yao, Y.; Yang, X.; Tian, J.; Liu, C.; Cheng, X.; Ren, G. Antioxidant and Antidiabetic Activities of Black Mung Bean (Vigna radiata L.). J. Agric. Food Chem. 2013, 61, 8104-8109. [CrossRef] [PubMed]

3. Reverri, E.J.; Randolph, J.M.; Kappagoda, C.T.; Park, E.; Edirisinghe, I.; Burton-Freeman, B.M. Assessing beans as a source of intrinsic fiber on satiety in men and women with metabolic syndrome. Appetite 2017, 118, 75-81. [CrossRef] [PubMed]

4. Millán-Linares, M.d.C.; Bermúdez, B.; Yust, M.d.M.; Millán, F.; Pedroche, J. Anti-inflammatory activity of lupine (Lupinus angustifolius L.) protein hydrolysates in THP-1-derived macrophages. J. Funct. Foods 2014, 8, 224-233. [CrossRef]

5. Jang, D.S.; Park, E.J.; Hawthorne, M.E.; Vigo, J.S.; Graham, J.G.; Cabieses, F.; Santarsiero, B.D.; Mesecar, A.D.; Fong, H.H.S.; Mehta, R.G.; et al. Potential Cancer Chemopreventive Constituents of the Seeds of Dipteryx odorata (Tonka Bean). J. Nat. Prod. 2003, 66, 583-587. [CrossRef] [PubMed]

6. Siah, S.D.; Konczak, I.; Agboola, S.; Wood, J.A.; Blanchard, C.L. In vitro investigations of the potential health benefits of Australian-grown faba beans (Vicia faba L.): Chemopreventative capacity and inhibitory effects on the angiotensin-converting enzyme, $\alpha$-glucosidase and lipase. Br. J. Nutr. 2012, 108, S123-S134. [CrossRef] [PubMed]

7. Sánchez-Chino, X.; Jiménez-Martínez, C.; Dávila-Ortiz, G.; Álvarez-González, I.; Madrigal-Bujaidar, E. Nutrient and Nonnutrient Components of Legumes, and Its Chemopreventive Activity: A Review. Nutr. Cancer 2015, 67, 401-410. [CrossRef] [PubMed]

8. Zhang, X.; Shang, P.; Qin, F.; Zhou, Q.; Gao, B.; Huang, H.; Yang, H.; Shi, H.; Yu, L. Chemical composition and antioxidative and anti-inflammatory properties of ten commercial mung bean samples. LWT_Food Sci. Technol. 2013, 54, 171-178. [CrossRef]

9. Dong, M.; He, X.; Liu, R.H. Phytochemicals of Black Bean Seed Coats: Isolation, Structure Elucidation, and Their Antiproliferative and Antioxidative Activities. J. Agric. Food Chem. 2007, 55, 6044-6051. [CrossRef] [PubMed]

10. Yun-Kyoung, L.; Jin-Taek, H.; Mee-Sook, L.; Young-Min, K.; Jin, P.O. Kidney Bean Husk Extracts Exert Antitumor Effect by Inducing Apoptosis Involving AMP-Activated Protein Kinase Signaling Pathway. Ann. N. Y. Acad. Sci. 2009, 1171, 484-488.

11. Cruz-Bravo, R.K.; Guevara-Gonzalez, R.; Ramos-Gomez, M.; Garcia-Gasca, T.; Campos-Vega, R.; Oomah, B.D.; Loarca-Piña, G. Fermented Nondigestible Fraction from Common Bean (Phaseolus vulgaris L.) Cultivar Negro 8025 Modulates HT-29 Cell Behavior. J. Food Sci. 2011, 76, T41-T47. [CrossRef] [PubMed]

12. Sosulski, F.W.; Dabrowski, K.J. Composition of Free and Hydrolyzable Phenolic-Acids in the Flours and Hulls of 10 Legume Species. J. Agric. Food Chem. 1984, 32, 131-133. [CrossRef]

13. Giusti, F.; Caprioli, G.; Ricciutelli, M.; Vittori, S.; Sagratini, G. Determination of fourteen polyphenols in pulses by high performance liquid chromatography-diode array detection (HPLC-DAD) and correlation study with antioxidant activity and colour. Food Chem. 2017, 221, 689-697. [CrossRef] [PubMed]

14. Boudjou, S.; Oomah, B.D.; Zaidi, F.; Hosseinian, F. Phenolics content and antioxidant and anti-inflammatory activities of legume fractions. Food Chem. 2013, 138, 1543-1550. [CrossRef] [PubMed]

15. Garcia-Mora, P.; Frias, J.; Peñas, E.; Zieliński, H.; Giménez-Bastida, J.A.; Wiczkowski, W.; Zielińska, D.; Martínez-Villaluenga, C. Simultaneous release of peptides and phenolics with antioxidant, ACE-inhibitory and anti-inflammatory activities from pinto bean (Phaseolus vulgaris L. var. pinto) proteins by subtilisins. J. Funct. Foods 2015, 18, 319-332. [CrossRef] 
16. Kan, L.; Nie, S.; Hu, J.; Liu, Z.; Xie, M. Antioxidant activities and anthocyanins composition of seed coats from twenty-six kidney bean cultivars. J. Funct. Foods 2016, 26, 622-631. [CrossRef]

17. Hua, C.; Hai-Rong, M.; Yan-Hua, G.; Xue, Z.; Madina, H.; Rui, H.; Akber, A.H. Isoflavones Extracted from Chickpea Cicer arietinum L. Sprouts Induce Mitochondria-Dependent Apoptosis in Human Breast Cancer Cells. Phytother. Res. 2015, 29, 210-219.

18. Segura-Nieto, M.; Jim, E.R. Genetic Modifications of Plant Seed Storage Proteins for Food Production; Technomic Publishing: Lancaster, PA, USA, 1999.

19. Sharon, N.; Lis, H. Legume lectins-A large family of homologous proteins. FASEB J. 1990, 4, 3198-3208. [CrossRef] [PubMed]

20. Laskowski, M., Jr.; Kato, I. Protein Inhibitors of Proteinases. Ann. Rev. Biochem. 1980, 49, 593-626. [CrossRef] [PubMed]

21. Padhi, E.M.T.; Liu, R.; Hernandez, M.; Tsao, R.; Ramdath, D.D. Total polyphenol content, carotenoid, tocopherol and fatty acid composition of commonly consumed Canadian pulses and their contribution to antioxidant activity. J. Funct. Foods 2017, 38, 602-611. [CrossRef]

22. Kan, L.; Nie, S.; Hu, J.; Wang, S.; Bai, Z.; Wang, J.; Zhou, Y.; Jiang, J.; Zeng, Q.; Song, K. Comparative study on the chemical composition, anthocyanins, tocopherols and carotenoids of selected legumes. Food Chem. 2018, 260, 317-326. [CrossRef] [PubMed]

23. Cooper, G.M. The Development and Causes of Cancer, 2nd ed.; Sinauer Associates: Sunderland, MA, USA, 2000.

24. Aparicio-Fernández, X.; Reynoso-Camacho, R.; Castaño-Tostado, E.; García-Gasca, T.; González de Mejía, E.; Guzmán-Maldonado, S.H.; Elizondo, G.; Yousef, G.G.; Lila, M.A.; Loarca-Pina, G. Antiradical Capacity and Induction of Apoptosis on HeLa Cells by a Phaseolus vulgaris Extract. Plant Foods Hum. Nutr. 2008, 63, 35-40. [CrossRef] [PubMed]

25. Mudryj, A.N.; Yu, N.; Aukema, H.M. Nutritional and health benefits of pulses. Appl. Physiol. Nutr. Metab. 2014, 39, 1197-1204. [CrossRef] [PubMed]

26. Guadagni, F.; Ferroni, P.; Palmirotta, R.; Portarena, I.; Formica, V.; Roselli, M. Review. TNF/VEGF cross-talk in chronic inflammation-related cancer initiation and progression: An early target in anticancer therapeutic strategy. In Vivo 2007, 21, 147-161. [PubMed]

27. Limtrakul, P.; Yodkeeree, S.; Pitchakarn, P.; Punfa, W. Suppression of Inflammatory Responses by Black Rice Extract in RAW 264.7 Macrophage Cells via Downregulation of NF-kB and AP-1 Signaling Pathways. Asian Pac. J. Cancer Prev. 2015, 16, 4277-4283. [CrossRef] [PubMed]

28. Gilmore, T.D. Introduction to NF-kappaB: Players, pathways, perspectives. Oncogene 2006, 25, 6680-6684. [CrossRef] [PubMed]

29. Mantovani, A.; Garlanda, C.; Allavena, P. Molecular pathways and targets in cancer-related inflammation. Ann. Med. 2010, 42, 161-170. [CrossRef] [PubMed]

30. Mantovani, A.; Allavena, P.; Sica, A.; Balkwill, F. Cancer-related inflammation. Nature 2008, 454, $436-444$. [CrossRef] [PubMed]

31. Luo, J.; Cai, W.; Wu, T.; Xu, B. Phytochemical distribution in hull and cotyledon of adzuki bean (Vigna angularis L.) and mung bean (Vigna radiate L.), and their contribution to antioxidant, anti-inflammatory and anti-diabetic activities. Food Chem. 2016, 201, 350-360. [CrossRef] [PubMed]

32. Moreno-Jiménez, M.R.; Cervantes-Cardoza, V.; Gallegos-Infante, J.A.; González-Laredo, R.F.; Estrella, I.; García-Gasca, T.d.J.; Herrera-Carrera, E.; Díaz-Rivas, J.O.; Rocha-Guzmán, N.E. Phenolic composition changes of processed common beans: Their antioxidant and anti-inflammatory effects in intestinal cancer cells. Food Res. Int. 2015, 76, 79-85. [CrossRef]

33. López-Barrios, L.; Antunes-Ricardo, M.; Gutiérrez-Uribe, J.A. Changes in antioxidant and antiinflammatory activity of black bean (Phaseolus vulgaris L.) protein isolates due to germination and enzymatic digestion. Food Chem. 2016, 203, 417-424. [CrossRef] [PubMed]

34. Yeap, S.K.; Mohd Yusof, H.; Mohamad, N.E.; Beh, B.K.; Ho, W.Y.; Ali, N.M.; Alitheen, N.B.; Koh, S.P.; Long, K. In Vivo Immunomodulation and Lipid Peroxidation Activities Contributed to Chemoprevention Effects of Fermented Mung Bean against Breast Cancer. Evid.-Based Complement. Altern. Med. 2013, 2013, 708464. [CrossRef] [PubMed] 
35. Thompson, M.D.; Brick, M.A.; McGinley, J.N.; Thompson, H.J. Chemical Composition and Mammary Cancer Inhibitory Activity of Dry Bean All rights reserved. No part of this periodical may be reproduced or transmitted in any form or by any means, electronic or mechanical, including photocopying, recording, or any information storage and retrieval system, without permission in writing from the publisher. Permission for printing and for reprinting the material contained herein has been obtained by the publisher. Crop Sci. 2009, 49, 179-186.

36. García-Lafuente, A.; Moro, C.; Manchón, N.; Gonzalo-Ruiz, A.; Villares, A.; Guillamón, E.; Rostagno, M.; Mateo-Vivaracho, L. In vitro anti-inflammatory activity of phenolic rich extracts from white and red common beans. Food Chem. 2014, 161, 216-223. [CrossRef] [PubMed]

37. Sánchez, X.; Martinez, C.J.; Garzón, V.R.V.; Álvarez González, I.; Villa-Treviño, S.; Madrigal Bujaidar, E.; Dávila Ortiz, G.; Baltiérrez Hoyos, R. Cooked Chickpea Consumption Inhibits Colon Carcinogenesis in Mice Induced with Azoxymethane and Dextran Sulfate Sodium. J. Am. Coll. Nutr. 2017, 36, 391-398.

38. Xu, B.; Chang, S.K.C. Comparative study on antiproliferation properties and cellular antioxidant activities of commonly consumed food legumes against nine human cancer cell lines. Food Chem. 2012, 134, 1287-1296. [CrossRef] [PubMed]

39. Niveditha, V.R.; Venkatramana, D.K.; Sridhar, K.R. Cytotoxic effects of methanol extract of raw, cooked and fermented split beans of Canavalia on cancer cell lines MCF-7 and HT-29. IIOAB J. 2013, 4, 20-23.

40. Kim, D.K.; Jeong, S.C.; Gorinstein, S.; Chon, S.-U. Total Polyphenols, Antioxidant and Antiproliferative Activities of Different Extracts in Mungbean Seeds and Sprouts. Plant Foods Hum. Nutr. 2012, 67, 71-75. [CrossRef] [PubMed]

41. Ombra, M.N.; D’Acierno, A.; Nazzaro, F.; Riccardi, R.; Spigno, P.; Zaccardelli, M.; Pane, C.; Maione, M.; Fratianni, F. Phenolic Composition and Antioxidant and Antiproliferative Activities of the Extracts of Twelve Common Bean (Phaseolus vulgaris L.) Endemic Ecotypes of Southern Italy before and after Cooking. Oxid. Med. Cell. Longev. 2016, 2016, 1398298. [CrossRef] [PubMed]

42. Zou, Y.P.; Chang, K.-C. Antioxidant and Antiproliferative Properties of Extract and Fractions from Small Red Bean (Phaseolus vulgaris L.). J. Food Nutr. 2014. [CrossRef]

43. Chen, Z.; Wang, J.; Liu, W.; Chen, H. Physicochemical characterization, antioxidant and anticancer activities of proteins from four legume species. J. Food Sci. Technol. 2017, 54, 964-972. [CrossRef] [PubMed]

44. Ma, D.Z.; Wang, H.X.; Ng, T.B. A peptide with potent antifungal and antiproliferative activities from Nepalese large red beans. Peptides 2009, 30, 2089-2094. [CrossRef] [PubMed]

45. Wang, H.X.; Ng, T.B. Isolation and characterization of an antifungal peptide with antiproliferative activity from seeds of Phaseolus vulgaris cv. 'Spotted Bean'. Appl. Microbiol. Biotechnol. 2007, 74, 125-130. [CrossRef] [PubMed]

46. Magee, P.J.; Owusu-Apenten, R.; McCann, M.J.; Gill, C.I.; Rowland, I.R. Chickpea (Cicer arietinum) and Other Plant-Derived Protease Inhibitor Concentrates Inhibit Breast and Prostate Cancer Cell Proliferation In Vitro. Nutr. Cancer 2012, 64, 741-748. [CrossRef] [PubMed]

47. Joghatai, M.; Barari, L.; Mousavie Anijdan, S.H.; Elmi, M.M. The evaluation of radio-sensitivity of mung bean proteins aqueous extract on MCF-7, hela and fibroblast cell line. Int. J. Radiat. Biol. 2018, 94, 478-487. [CrossRef] [PubMed]

48. Lam, S.K.; Ng, T.B. Isolation and characterization of a French bean hemagglutinin with antitumor, antifungal, and anti-HIV-1 reverse transcriptase activities and an exceptionally high yield. Phytomedicine 2010, 17, 457-462. [CrossRef] [PubMed]

49. Wong, J.H.; Ng, T.B. A homotetrameric agglutinin with antiproliferative and mitogenic activities from haricot beans. J. Chromatogr. B-Anal. Technol. Biomed. Life Sci. 2005, 828, 130-135.

50. Wang, S.; Rao, P.; Ye, X. Isolation and biochemical characterization of a novel leguminous defense peptide with antifungal and antiproliferative potency. Appl. Microbiol. Biotechnol. 2009, 82, 79-86. [CrossRef] [PubMed]

51. Ngai, P.H.K.; Ng, T.B. Coccinin, an antifungal peptide with antiproliferative and HIV-1 reverse transcriptase inhibitory activities from large scarlet runner beans. Peptides 2004, 25, 2063-2068. [CrossRef] [PubMed]

52. Wang, S.; Lin, J.; Ye, M.; Ng, T.B.; Rao, P.; Ye, X. Isolation and characterization of a novel mung bean protease inhibitor with antipathogenic and anti-proliferative activities. Peptides 2006, 27, 3129-3136. [CrossRef] [PubMed] 
53. Ang, A.S.W.; Cheung, R.C.F.; Dan, X.; Chan, Y.S.; Pan, W.; Ng, T.B. Purification and Characterization of a Glucosamine-Binding Antifungal Lectin from Phaseolus vulgaris cv. Chinese Pinto Beans with Antiproliferative Activity Towards Nasopharyngeal Carcinoma Cells. Appl. Biochem. Biotechnol. 2014, 172, 672-686. [CrossRef] [PubMed]

54. Sun, J.; Wang, H.; Ng, T.B. Trypsin Isoinhibitors with Antiproliferative Activity toward Leukemia Cells from Phaseolus vulgaris cv White Cloud Bean. J. Biomed. Biotechnol. 2010, 2010, 219793. [CrossRef] [PubMed]

55. Clemente, A.; Carmen Marín-Manzano, M.; Jiménez, E.; Carmen Arques, M.; Domoney, C. The anti-proliferative effect of TI1B, a major Bowman-Birk isoinhibitor from pea (Pisum sativum L.), on HT29 colon cancer cells is mediated through protease inhibition. Br. J. Nutr. 2012, 108, S135-S144. [CrossRef] [PubMed]

56. Barari, L.; Abedian, Z.; Asadi, A.; Elmi, F.; Elmi, M. Anti-proliferative Effect of Chickpea Extract on Hela, MCF-7, Saos and Fibroblast Cell Lines. Br. J. Pharm. Res. 2017, 15, 1-9. [CrossRef]

57. Kumar, S.; Kapoor, V.; Gill, K.; Singh, K.; Xess, I.; Das, S.N.; Dey, S. Antifungal and Antiproliferative Protein from Cicer arietinum: A Bioactive Compound against Emerging Pathogens. BioMed Res. Int. 2014, 2014, 387203. [CrossRef] [PubMed]

58. Loizzo, M.R.; Rashed, K.; Said, A.; Bonesi, M.; Menichini, F.; Tundis, R. Antiproliferative and antioxidant properties of Alhagi maurorum Boiss (Leguminosae) aerial parts. Ind. Crops Prod. 2014, 53, 289-295. [CrossRef]

59. Bennink, M.R. Consumption of Black Beans and Navy Beans (Phaseolus vulgaris) Reduced Azoxymethane-Induced Colon Cancer in Rats. Nutr. Cancer 2002, 44, 60-65. [CrossRef] [PubMed]

60. Aparicio-Fernández, X.; García-Gasca, T.; Yousef, G.G.; Lila, M.A.; González de Mejia, E.; Loarca-Pina, G. Chemopreventive Activity of Polyphenolics from Black Jamapa Bean (Phaseolus vulgaris L.) on HeLa and HaCaT Cells. J. Agric. Food Chem. 2006, 54, 2116-2122. [CrossRef] [PubMed]

61. Hafidh, R.R.; Abdulamir, A.S.; Bakar, F.A.; Jalilian, F.A.; Abas, F.; Sekawi, Z. Novel molecular, cytotoxical, and immunological study on promising and selective anticancer activity of Mung bean sprouts. BMC Complement. Altern. Med. 2012, 12, 208. [CrossRef] [PubMed]

62. Busambwa, K.; Sunkara, R.; Diby, N.; Offei-Okyne, R.; Boateng, J.; Verghese, M. Cytotoxic and Apoptotic Effects of Sprouted and Non-sprouted Lentil, Green and Yellow Split-peas. Int. J. Cancer Res. 2016, 12, 51-60.

63. Thompson, M.D.; Thompson, H.J.; Brick, M.A.; McGinley, J.N.; Jiang, W.; Zhu, Z.; Wolfe, P. Mechanisms Associated with Dose-Dependent Inhibition of Rat Mammary Carcinogenesis by Dry Bean (Phaseolus vulgaris, L.). J. Nutr. 2008, 138, 2091-2097. [CrossRef] [PubMed]

64. Aregueta-Robles, U.; Fajardo-Ramirez, O.R.; Villela, L.; Gutierrez-Uribe, J.A.; Hernandez-Hernandez, J.; Lopez-Sanchez, R.D.; Scott, S.P.; Serna-Saldivar, S. Cytotoxic Activity of a Black Bean (Phaseolus Vulgaris L.) Extract and Its Flavonoid Fraction in Both in Vitro and in Vivo Models of Lymphoma. Rev. Investig. Clin.-Clin. Transl. Investig. 2018, 70, 32-39. [CrossRef] [PubMed]

65. Stanisavljević, N.S.; Ilić, M.D.; Matić, I.Z.; Jovanović, Ž.S.; Čupić, T.; Dabić, D.Č.; Natić, M.M.; Tešić, Ž.L. Identification of Phenolic Compounds from Seed Coats of Differently Colored European Varieties of Pea (Pisum sativum L.) and Characterization of Their Antioxidant and In Vitro Anticancer Activities. Nutr. Cancer 2016, 68, 988-1000. [CrossRef] [PubMed]

66. Luna-Vital, D.A.; de Mejia, E.G.; Dia, V.P.; Loarca-Pina, G. Peptides in common bean fractions inhibit human colorectal cancer cells. Food Chem. 2014, 157, 347-355. [CrossRef] [PubMed]

67. Luna-Vital, D.A.; González de Mejía, E.; Loarca-Piña, G. Selective mechanism of action of dietary peptides from common bean on HCT116 human colorectal cancer cells through loss of mitochondrial membrane potential and DNA damage. J. Funct. Foods 2016, 23, 24-39. [CrossRef]

68. Dan, X.; Ng, T.B.; Wong, J.H.; Chan, Y.S.; Cheung, R.C.F.; Chan, W.Y. A hemagglutinin isolated from Northeast China black beans induced mitochondrial dysfunction and apoptosis in colorectal cancer cells. Biochim. Biophys. Acta (BBA)—Mol. Cell Res. 2016, 1863, 2201-2211. [CrossRef] [PubMed]

69. Chan, Y.S.; Xia, L.; Ng, T.B. White kidney bean lectin exerts anti-proliferative and apoptotic effects on cancer cells. Int. J. Biol. Macromol. 2016, 85, 335-345. [CrossRef] [PubMed]

70. Chan, Y.S.; Yu, H.; Xia, L.; Ng, T.B. Lectin from green speckled lentil seeds (Lens culinaris) triggered apoptosis in nasopharyngeal carcinoma cell lines. Chin. Med. 2015, 10, 25. [CrossRef] [PubMed]

71. Li, Z.; Zhao, C.; Li, Z.; Zhao, Y.; Shan, S.; Shi, T.; Li, J. Reconstructed mung bean trypsin inhibitor targeting cell surface GRP78 induces apoptosis and inhibits tumor growth in colorectal cancer. Int. J. Biochem. Cell Biol. 2014, 47, 68-75. [CrossRef] [PubMed] 
72. Feregrino-Perez, A.A.; Piñol-Felis, C.; Gomez-Arbones, X.; Guevara-González, R.G.; Campos-Vega, R.; Acosta-Gallegos, J.; Loarca-Piña, G. A Non-digestible Fraction of the Common Bean (Phaseolus vulgaris L.) Induces Cell Cycle Arrest and Apoptosis During Early Carcinogenesis. Plant Foods Hum. Nutr. 2014, 69, 248-254. [CrossRef] [PubMed]

73. Cruz-Bravo, R.K.; Guevara-González, R.G.; Ramos-Gómez, M.; Oomah, B.D.; Wiersma, P.; Campos-Vega, R.; Loarca-Piña, G. The fermented non-digestible fraction of common bean (Phaseolus vulgaris L.) triggers cell cycle arrest and apoptosis in human colon adenocarcinoma cells. Genes Nutr. 2013, 9, 359. [CrossRef] [PubMed]

74. Campos-Vega, R.; Guevara-Gonzalez, R.G.; Guevara-Olvera, B.L.; Dave Oomah, B.; Loarca-Piña, G. Bean (Phaseolus vulgaris L.) polysaccharides modulate gene expression in human colon cancer cells (HT-29). Food Res. Int. 2010, 43, 1057-1064. [CrossRef]

75. Lima, A.I.G.; Mota, J.; Monteiro, S.A.V.S.; Ferreira, R.M.S.B. Legume seeds and colorectal cancer revisited: Protease inhibitors reduce MMP-9 activity and colon cancer cell migration. Food Chem. 2016, 197, 30-38. [CrossRef] [PubMed]

76. Banerji, A.; Fernandes, A.; Bane, S.; Ahire, S. The field bean protease inhibitor has the potential to suppress B16F10 melanoma cell lung metastasis in mice. Cancer Lett. 1998, 129, 15-20. [CrossRef]

(C) 2018 by the authors. Licensee MDPI, Basel, Switzerland. This article is an open access article distributed under the terms and conditions of the Creative Commons Attribution (CC BY) license (http://creativecommons.org/licenses/by/4.0/). 